


ISSN 1392-6195 (print) ISSN 2029-2058 (online) JURISPRUDENCIJA JURISPRUDENCE 2014, 21(4), p. 974-987.

\title{
ARE THE CONDITIONS OF STATEHOOD SUFFICIENT? AN ARGUMENT IN FAVOUR OF POPULAR SOVEREIGNTY AS AN ADDITIONAL CONDITION OF STATEHOOD
}

\author{
Christoforos Ioannidis \\ King's College London, The Dickson Poon School of Law \\ Somerset House East Wing \\ WC2R 2LS, London, United Kingdom \\ Tel.: +44 (0)2078482479 \\ E-mail: law-department@kcl.ac.uk
}

Submitted on 6 October, 2014; accepted on 10 December, 2014

doi:10.13165/JUR-14-21-4-03

\section{Introduction}

Together with international organisations, states are the main subjects of public international law (PIL). However, the theories of their creation seem highly problematic. This poses problems for the development of PIL in overall. If entities without any signs of popular sovereignty could become states, it would be harder to foster human rights in the international realm, a goal of PIL which gradually gets more and more acceptance, since in domestic legal orders human rights are best protected in democracies. The purpose of this paper is to suggest a thin, thus more feasible, idea of popular sovereignty as a condition of statehood. The author of this paper will first evaluate the two main theories of statehood in PIL and then suggest popular sovereignty as a requirement for statehood. Then, the author will comment

Jurisprudencija/Jurisprudence

(C) Mykolo Romerio universitetas, 2014

(C) Mykolas Romeris University, 2014
ISSN 1392-6195 (print), ISSN 2029-2058 (online) http://www.mruni.eu/lt/mokslo_darbai/jurisprudencija/ http://www.mruni.eu/en/mokslo_darbai/jurisprudencija/ 
on what position popular sovereignty can be regarded as having in relation to the other existing conditions of statehood by entertaining the thought of whether popular sovereignty could be a necessary or sufficient condition. After that, the author will try to connect the suggestion of popular sovereignty as a condition for statehood with Buchanan's suggestion of justice in the sense of realization of basic human rights as the primary goal of international law. Finally, because human rights are presented as a moral value and in Natural Law Theory unethical law is not law, it will be explained why it is that neither Buchanan's view nor the author's view are Natural Law views and that this entire discussion falls under the spectrum of Legal Positivism.

\section{The two competing theories of state recognition: Constitutive and Declarative theories}

According to the Constitutive theory of statehood, a state is a subject of international law if, and only if, it is recognized as sovereign by other states ${ }^{1}$. Because of this, new states cannot immediately become part of the international community or be bound by international law, and recognized nations do not have to respect international law in their dealings with them ${ }^{2}$. The most compelling argument against the constitutive theory is that it leads to a relativity of the state as a subject of international law. States are not relative subjects of international law created by other states like international organisations. The idea of one state deciding upon another state's personality in international law is at odds with the fundamental principle of the sovereign equality of states. The Constitutive theory is indeed an expression of an outdated, positivist view of international law as purely consensual system, where legal relations can only arise with the consent of those concerned ${ }^{3}$.

By contrast, according to the Declarative theory, an entity's statehood is independent of its recognition by other states. This is stated in Article 2 of the Montevideo Convention on the Rights and Duties of States (1933). More specifically, the Declarative theory, as stated in Article 1 of the aforementioned Convention, identifies the state as a person in international law if it meets the following criteria: 1) a defined territory, 2) a permanent population, 3) a government and 4) a capacity to enter into relations with other states.

1 Oppenheim, L. F. L. International Law: A Treatise. Sir Hersch Lauterpacht 8th ed. London: Longmans, Green and Co., 1955, p. 125, in Grant, T. D. The Recognition of States Law and Practice in Debate and Revolution. Chapter 1. The once -great debate and its rivals, The Constitutive model, paragraph 1.

2 See, e.g., Hillier, T. Sourcebook on Public International Law. Routledge, 1998, p. 201-2.

3 Talmon, S. The Constitutive Versus the Declaratory Theory of Recognition: Tertium non Datur? British Yearbook of International Law. 2004, 75(1): 101-181. 


\section{State practice}

Although one might expect that the international realm would strictly follow the Declarative theory of state recognition because of the fact that it is the one expressly stipulated in an international convention, state practice seems to be situated somewhat between the two theories ${ }^{4}$. In particular, both Croatia and Bosnia and Herzegovina were recognized as independent states by European Community member states and admitted to membership of the United Nations (which, according to Article 4 of the UN Charter, is limited to states) in 1992 at a time where in both states non-governmental forces controlled substantial areas of the territories in question in civil war conditions. Also, recognition is often withheld when a new state is regarded as illegitimate or has come about in breach of international law. Almost universal non-recognition by the international community of Rhodesia and Northern Cyprus are good examples of this. In the former case, recognition was widely withheld when the white minority seized power and attempted to form a state along the lines of Apartheid South Africa, a move that the United Nations Security Council described as the creation of an "illegal racist minority regime" . In the latter case, recognition was widely withheld from a regime created in Northern Cyprus on land illegally invaded by Turkey in $1974^{6}$. In general, it seems that Broms is right to observe that in actual practice, the criteria are mainly political rather legal ${ }^{7}$.

\section{Logical circularity of the fourth condition}

More importantly, the Declarative theory cannot possibly apply properly because of two reasons. The first reason is that the fourth condition is logically circular. In order for an entity to become a state, it ought to have the capacity to enter into relations with other states. However, in order to have the capacity to enter into relations with other states, an entity ought to already be a state, since the relations we are talking about are relations exclusively among states. From the negative side of things "whoever is not recognized is unable to enter into relations with other states and, precisely because of his inability to enter into relations, does not meet the

4 Malcolm, S. International Law. 6th ed. Cambridge University Press online version, 2008 [interactive]. [accessed on 2014-10-07] King's College London Libraries, p. 197, The relationship in this area between factual and legal criteria has been is a crucial shifting one. United Nations Security Council Resolution 216.

$6 \quad$ United Nations Security Council Resolution 541.

7 "...one is led to the conclusion that the granting of recognition has become primarily a legalpolitical solution whereby the political element weighs heavier than the legal one.", in Broms, B. IV Recognition of States. International Law: Achievements and Prospects. UNESCO Series, Mohammed Bedjaoui (ed.), Martinus Nijhoff Publishers, 1991, p. 47-48. 
conditions for recognition as a state." 7 Therefore, the last condition obviously does not work.

\section{Conditions of statehood and conditions of recognition}

The second reason why the Declarative theory as it is cannot properly apply is that the capacity to enter into relations with other states is contingent on the issue of recognition. Thus, one would think that it makes sense to look at the state practice of state recognition. However, analyzing state practice in this particular topic makes one fall into the trap of moving from conditions of statehood (recognition of a state) to conditions of recognition (recognition as a state) ${ }^{9}$. The former is prescribed by public international law (PIL) and it is what interests us here, whereas the second varies from state to state and it is rather political. States' decisions to recognize are based on political reasons. For example, Turkey, for some obvious and some not so obvious political reasons, chooses not to recognize the Republic of Cyprus as a state, although it is a state under PIL.

\section{The gap of the fourth condition}

It could be argued that the fourth condition should just be ignored and only the first three must remain. After all, the creation of a state is a socio-political process. Therefore, only the first three conditions must remain because they are part of that process. Both of these statements are true, but they do not prove that the fourth condition ought not to exist. Indeed, the creation of the state is a sociopolitical process. However, legal consequences arise from facts. Indeed, the first three conditions are parts of the socio-political process of the creation of these entities. However, there is a point in there being a fourth condition which is not part of this process. It is the condition which ascribes legal consequences to the facts. It is the condition which, if met, elevates an entity - which satisfies merely the three first conditions - to a state. 'Entity' is not a legal term. It does not ascribe a legal status, e.g., the status of a subject of PIL. By contrast, 'state' is a legal term. States are full subjects of PIL, whereas entities are not. Therefore, the fourth condition ought to be a condition which, if met, ascribes legal consequences to the facts, i.e. ascribes legality to the entity and upgrades it to a state.

\section{Popular sovereignty as the fourth condition of statehood}

The author of this paper suggests that popular sovereignty in a specific historical sense be regarded as the fourth necessary requirement for statehood. This is a clearly 
deontological statement, so the author argues why it should be so, without making any ontological claims. The popular sovereignty requirement that the author is advancing is as follows: a necessary requirement for an entity to be a state is that at one specific point in time, the majority of an identifiable number of people permanently living within an identifiable territory and having a government freely vote ${ }^{10}$ for a constitution. For the action of voting to be free, voters must be exercising self-rule or, in other words, their individual autonomy, the standard requirements ${ }^{11}$ of which are the following:

a) The action has to be intentional, i.e., the voters must intentionally be performing the action of expressing their opinion of whether they want to bring that specific constitution into effect. In a hypothetical imaginative scenario where voters vote for a constitution while intending to vote for inclusion to another state, their action does not count as a free action.

b) The action has to be based on sufficient understanding. Several reasons can cause lack of understanding, two of which are lack of information and lack of mental capacities of understanding, which should also exclude children. Adequate information requires that the people have been informed of the constitution well advance so that they had enough time to read it and hopefully reflect on it.

c) The action has to be free from external constraints. These include physical barriers deliberately imposed by others and different forms of coercion, including deliberate use of force or the threat of harm. The coercer's purpose is to get the person being coerced to do something that that person would not actually be willing to do. Therefore, for example, if people are threatened that if they vote for the constitution the nearby state will invade, then the act of voting is not free.

d) The action has to be free from internal constraints. Examples of internal constraints are intense fears and acute pain as they influence people to make choices that represent departures from their stable values and usual priorities. Therefore, for example, voting which takes part right after a regime causes the emotion of extreme fear is not free.

10 In this discussion, freedom and autonomy overlap and can be used interchangeably, as is usually the case. Some writers make a distinction between the two terms which is here not relevant because freedom/autonomy refer to one specific action, i.e. the voting of the constitution. Such writers are Dworkin who maintains that freedom concerns particular acts, whereas autonomy is a more global notion. See Dworkin, G. The Theory and Practice of Autonomy. New York: Cambridge University Press, 1988, p. 13-15, 19-20.

11 Regardless of the specific articulation and the specific content in which they function, the author of this paper regards these to be the standard requirements of autonomy in philosophy. See, e.g., Mappes, A. T., and Degrazia, D. Biomedical Ethics. 6th ed. McGraw-Hill Higher Education, 2006, p. 41-45. 


\section{Popular sovereignty: necessary and/or sufficient condition for statehood?}

The author of this paper suggested that an entity should not be able to obtain the status of statehood unless it satisfies the popular sovereignty requirement. Therefore, popular sovereignty is a necessary condition for statehood. Now, whether popular sovereignty is also a sufficient condition for statehood is going to be explored.

It would be hard to imagine a state that does not satisfy the first three requirements of the Montevideo Convention - territory, population and government ${ }^{12}$. An entity that does not satisfy these criteria is an entity that would probably not be relevant to the discussion of statehood. Therefore, one could conclude that if the requirement of popular sovereignty is accepted, it can only be a necessary but not a sufficient condition, because it being a sufficient condition would entail that an entity can be a state without satisfying those three requirements, which sounds absurd.

If that is the case, then how does the constitutive theory make any sense? If the constitutive theory means that recognition by other states is a necessary and sufficient condition for state recognition, whereas the territory/population/government requirements are not necessary conditions and an entity can be a state without them as long as it is recognized by other states, then the Constitutive theory is equally absurd. Notably, the distinction between the two theories is not that these three requirements are regarded as necessary by the Declarative theory alone, whereas the Constitutive theory does not regard them as necessary, but the issue of recognition ${ }^{13}$. The difference between the two theories is that the Constitutive theory makes statehood contingent on recognition from other states, whereas the Declarative theory does not. Therefore, to make more sense of the Constitutive theory, one would have to include the territory/population/government requirements in order to be able to talk about any kind of regime in the first place. Seen in this light, the Constitutive theory implies the three aforementioned requirements. By the same token, popular sovereignty can be seen as implying, and thus, necessarily including the territory/population/government requirements. This would mean that when referring to certain people freely voting for a constitution, we assume that we are referring to an identifiable group of people, permanently living within an identifiable territory and having a form of government which would allow the people to decide whether to vote for a constitution. To the author of the paper, this does not seem to be too much of a stretch.

12 The examples of Croatia and Bosnia and Herzegovina mentioned above relate to recognition as a state, not recognition of a state.

13 Worster, W. Sovereignty Two Competing Theories of State Recognition [interactive]. [accessed on 2014-10-07]. <http://www.exploringgeopolitics.org/Publication_Worster_William_ Sovereignty_Constitutive_Declatory_Statehood_Recognition_Legal_View_International_ Law_Court_Justice_Montevideo_Genocide_Convention.html> . 
The requirement that has been left out is the capacity to enter into relations with other states. According to the popular sovereignty theory the author is proposing, it is not the case that capacity to enter into relations with other states is a necessary condition for statehood, as the Declarative theory suggests. By contrast, the popular sovereignty theory the author is suggesting regards the capacity to enter into relations with other states as a consequence of statehood, so the existence of the capacity necessarily requires that the status of statehood has been obtained first.

A comment that many would feel ought to be made here is that states are not the only ones which enter into relations with states. International organisations and other non-state entities enter into relations with other states. Therefore, it could be argued that entering into relations with states is not by itself a manifestation of statehood. This is entirely true and two comments can be made here. Firstly, the issue of nonstate entities entering into relations with states leaves author's argument entirely unaffected because the author does not maintain that entering into relations with states is a characteristic of states alone. What the author is suggesting is that in the case of statehood in particular, the capacity of entering into relations with other states as a consequence of statehood and not as a requirement can be seen. This position is neutral to whether non-state entities can enter into relations with other states, though modern international law and the emergence of transnational law make it relatively easy to provide a straightforward answer. Besides, if one would want to entertain the grammatical stipulation of the theory, reliance on the word 'other' in the expression 'other states' suggests that the capacity of entering into relations with other states in the context of this discussion has to do with states alone, which is rather unsurprising since both the Constitutive and the Declarative theory are theories of statehood and should not be seen as making any claims regarding non-state entities.

Therefore, if one wants to get on board with the popular sovereignty theory, he would be confronted with three choices. The first choice would be to regard the popular sovereignty requirement which necessarily encompasses the territory/ population/government element as a necessary and sufficient condition for statehood. The second choice would be to keep the articulation of the Declarative theory, at the same time enjoying the privilege of being closer to the letter of the theory laid down in codified international law, and merely add the popular sovereignty condition as another necessary but not sufficient condition. In this case, the popular sovereignty condition would be deprived of the territory/population/government element in order to avoid repetition and one would also require a capacity of entering into relations with other states. The capacity to enter into relations with other states would serve a rather cosmetic role. Finally, the last choice would be the same as the second one, but without the capacity of entering into relations with other states as that would be regarded as a consequence of statehood and not a requirement. The author of this paper strongly believes that the important issue is whether one would accept the popular sovereignty in the historical sense as the author presented it, 
namely the fact that at one specific point in time a group of people freely voted for a constitution, as a necessary condition of statehood. The author regards the choice among the three aforementioned options as a minor issue. Personally, the author of the present study opts for the first option for two main reasons. Firstly, presenting popular sovereignty in that rich sense as a necessary and sufficient condition makes it clear that in the discussion of statehood, the important component is the voting of a constitution. Besides, the territory and the population do not have to be exact, but merely identifiable. The government does not, officially at least, need to satisfy any internal/substantial criteria, i.e., it does not need to be particularly democratic, observe human rights, or be a 'good' government in any substantial sense. Although many theorists advance the suggestion that governments must be democratic, it is not the case - fortunately or unfortunately - that international law requires democracy as a necessary condition for statehood. Therefore, some flexibility is allowed in these conditions. On the contrary, the voting of the constitution has to be free according to the requirements mentioned above. Besides, when there is a discussion about whether an entity should obtain statehood, it is usually the case that it enjoys the territory/ population/government criteria, or else the discussion would not arise. The second and relevant reason is that popular sovereignty, being in the centre of this theory, is exactly what is justified by what the author agrees to be regarded as being the primary goal of international law, namely justice in the sense of a minimum protection of basic human rights.

Although the elements of territory/population/government/capacity to enter in relations with other states - when seen independently and irrelevant to the popular sovereignty requirement - are entirely factual circumstances that can be determined by force and which may be resulting in gross injustices, there is a certain moral aspect in the right of a group to govern themselves with a constitution. This requirement is in line with the recognized notion of self-determination (the author is intentionally avoiding any reference to 'right' of self-determination, because it seems to be the case that self-determination can itself be broken down in several other rights, but this is irrelevant to this discussion which is about statehood, not self-determination).

\section{Justice as the primary goal of international law}

There are two compelling reasons for accepting the theory of popular sovereignty stated above as the theory of statehood. Firstly, it is obviously more democratic, because it is based on the direct will of the people, or at least the majority of the people. Secondly, and in author's opinion more importantly, it promotes what Buchanan in Justice, Legitimacy and Self-Determination rightly advances as a de lege ferenda primary goal of PIL, namely justice, in the sense of protection of basic human rights. Justice is better served when human rights are observed. 
The author of the present paper agrees with Buchanan that it is reasonable to regard justice, meaning protection of basic human rights, as the primary goal of PIL $^{14}$. That would leave peace, which is currently regarded as the primary goal of PIL because of the way it is presented in the UN Charter, as the second goal in line. However, this does not mean that justice and peace are always in tension. Justice largely subsumes peace. Justice requires the prohibition of wars of aggression because wars of aggression inherently violate human rights. To that extent, the pursuit of justice is the pursuit of peace. Sometimes, justice requires violating peace and the fight of the Allies in the Second World War when they fought to stop fascist aggression with all its massive violations of human rights meets our moral intuitions that in such cases justice is worth more than peace. This exemplifies that in cases of conflict, the weight obviously lies to justice instead of peace. In other words, when justice and peace do come in tension, our intuitions clearly favour justice.

Here, it has to be stated that although the author agrees with Buchanan with justice being the primary goal of PIL, the popular sovereignty theory the author advances departs from Buchanan's theory on statehood, which disregards the issue of popular sovereignty, holding the position that statehood ought to be granted to entities that observe human rights. Although the author of the paper finds his theory very persuasive and much better grounded than either the Constitutive or the Declarative theory, the author thinks that the popular sovereignty theory has two simple advantages over Buchanan's theory. Firstly, the popular sovereignty theory is much more easily observed, and in this specific sense, much more realistic. Buchanan's suggestion requires the existence and impartial functioning of institutions that would observe whether the entity in question actually observes human rights. Although the author is very sympathetic to this idea, there are some doubts whether institutions will necessarily be unbiased simply because they are non-state entities. Secondly, although protecting human rights is indeed in full accordance with the definition of justice, when it comes to statehood in particular, what must also be seriously considered is the issue of the will of the people. Let's suppose that within a given territory, entity A is striving for statehood. Entity A does refer to an identifiable population within identifiable territory and with a form of government. Let's suppose that this entity actually observes human rights and the protection of human rights is way above the minimum level of protection expected by the international community. However, for reasons irrelevant to human rights, people are not happy with that constitution. For example, let's suppose that that constitution lays down processes which slow down the system and reduce dramatically the economic development of the country and that these processes are laid down in non-amendable clauses of the constitution. Since there cannot be two entities A, let's suppose that there is a metaphysical world,

14 Buchanan, A. Justice, Legitimacy, and Self-Determination. Oxford University Press, 2004, p. 74-82. 
exactly identical to this one, but in the respective entity, let's call it " $A$ ", which has the same population, territory and government, the system again observes and protects human rights, but the level of protection of human rights is insignificantly lower than the level of protection provided by entity A, but of course, again, higher than the minimum level of protection expected by the international community. However, the people in entity " $\mathrm{A}$ " are much happier with the constitution they freely voted and the economic development of their entity. It seems that it would not be unreasonable to hold that the entity the international community would preferably be granting statehood to is entity " $\mathrm{A}$ ".

The author of the present paper does not wish to diminish Buchanan's view; on the contrary, it is very convincing and is a path of development of contemporary PIL. It is definitely regarded as a great progress in comparison to the Constitutive and Declarative theories. However, the author believes that there can be reasonable alternatives that take into account other factors apart from the protection of human rights when it comes to an all-things-considered decision about which theory is most appropriate for statehood. That said, the author totally agrees with Buchanan as justice in the sense of protection of human rights as the primary goal of international law.

\section{Stepping into Natural Law?}

In short, no. Both main points, namely Buchanan's suggested notion of justice as the primary goal of international law and the author's main argument of popular sovereignty in a specific historical sense as a requirement of statehood, are not to be regarded as relating to any kind of Natural Law Theory. It is not the case that the author maintains that any international norm which violates justice as ethical foundation of international law is, because of that reason, legally invalid.

Regardless of the specific legal positivist position that different philosophers of law might take, e.g., Kelsen and Hart, who are both legal positivists but greatly disagree in many points, the author of the present study takes the main proposition of Legal Positivism per se to be the following: in any legal system, whether a norm is legally valid, and hence whether it forms part of the law of that system, depends on its sources, not its merits ${ }^{15}$. Therefore, if one maintains that an international legal norm is valid because of its sources, or, in other words, that the reason of validity of an international legal norm is its sources, then this view would fall under the umbrella of positivist views. By contrast, if one regards that an international legal norm is valid because of its merits, or, in other words, that the merits of the law - e.g., whether the law if moral or immoral based on whatever theory - are the reason of validity of an international legal norm, then this view would fall under Natural Law Theory. 
Although one may be misled by the use of morality in the goals of international law, it is incorrect to assume that just because of the reference to a certain kind of moral value, this moral value is to be regarded as a criterion of validity of norms. That is most certainly not the case here. Neither Buchanan nor the author of this paper makes such claims. The claim that a norm is invalid because it is against justice is not made here. On the contrary, the author holds that justice is not the goal of international law, but it ought to be. This is a deontological, not an ontological statement. As Buchanan puts it, "justice is a goal in the sense of an ideal state of affairs, a moral target that we aim at, and which we can strive to continue to approach more closely, even if it is not possible ever to achieve it fully or perfectly"16. In practice, this goal has to do with many issues, e.g., how international law ought to develop, how international legal norms ought to be laid down, minimum requirements of the content of international legal norms, principles governing international institutions, what functions we ought to see international law as having, etc., but it is most certainly not to say that justice is a criterion of validity. It is, therefore, accepted that unjust laws are, sadly, legally valid because of their sources.

Similarly, the author of this paper does not maintain that international legal norms according to which states have already obtained statehood or norms according to which entities will obtain statehood in the future are in any way invalid because they were or might be unjust. On the contrary, the author recognizes the Declarative theory of statehood as the legally valid international norm regarding statehood (even though it has not always been applied with absolute consistency) and he is suggesting that it ought to change in the future.

Therefore, although Legal Positivism per se is not within the scope of this discussion, if one wishes to place these theories in the Legal Positivism vs. Natural Law Theory discussion, then both Buchanan's theory of justice - with which the author obviously agrees - as the primary goal of international law and the author's suggestion of popular sovereignty as a condition of statehood are both legal positivist and not natural law theories.

\section{Conclusion}

In conclusion, the author of this paper has briefly referred to the two main competitive theories of statehood in international law and then advanced his theory of popular sovereignty as a necessary and/or sufficient condition of statehood. It has been stated that there are three ways one could follow using the popular sovereignty argument in relation to the territory/population/government requirements and

16 Buchanan, A., supra note 14, p. 78. See also p. 77: "By a moral goal of the international system I mean a goal the system ought to promote, not one it does promote or has up to the present been designed to promote." 
the requirement of the capacity to enter relations with other states. It has also been stated that the author of this paper personally prefers the first version in which popular sovereignty is more robust and has a richer content, including the territory/ population/government requirements. Then, it has been explained how the author's theory is justified by Buchanan's position, that justice, in the sense of protection of basic human rights, and not peace, ought to be the primary goal of international law. Then, reasons have been offered why the author departs from Buchanan's notion of statehood, according to which requirement for statehood ought to be protection of basic human rights, excluding popular sovereignty. Lastly, the author has explained why neither Buchanan's theory, nor his own suggestion of popular sovereignty has to be confused with any Natural Law Theory, and that, as regards the Legal Positivism vs. Natural Law Theory debate, this discussion remains within the limits of the former.

\section{References}

Broms, B. IV Recognition of States. International Law: Achievements and Prospects. UNESCO Series, Mohammed Bedjaoui (ed.), Martinus Nijhoff Publishers, 1991.

Buchanan, A. Justice, Legitimacy, and Self-Determination. Oxford University Press, 2004.

Dworkin, G. The Theory and Practice of Autonomy. New York: Cambridge University Press, 1988.

Gardner, J. Legal Positivism: 51/2 Myths. American Journal of Jurisprudence. 2001, 46(1): 199-227.

Malcolm, S International Law. 6th ed. Cambridge University Press online version, 2008 [interactive]. [accessed on 2014-10-07] King's College London Libraries.

Mappes, A. T., and Degrazia, D. Biomedical Ethics. 6th ed. McGrawHill Higher Education, 2006.

Oppenheim, L. F. L. International Law: A Treatise. Sir Hersch Lauterpacht 8th ed. London: Longmans, Green and Co., 1955.

Talmon, S. The Constitutive Versus the Declaratory Theory of Recognition: Tertium non Datur? British Yearbook of International Law. 2004, 75(1): 101181.

United Nations Security Council Resolution 216.

United Nations Security Council Resolution 541.

Worster, W. Sovereignty Two Competing Theories of State Recognition [interactive]. [accessedon2014-10-07]. <http://www.exploringgeopolitics. org/Publication_Worster_Willliam_ Sovereignty_Constitutive_Declatory_ Statehood_Recognition_Legal_View_ International_Law_Court_Justice_ Montevideo_Genocide_Convention. html>. 


\title{
AR VALSTYBINGUMO PRIELAIDOS YRA PAKANKAMOS? ARGUMENTAS UŽ TAUTOS SUVERENITETĄ KAIP PAPILDOMĄ VALSTYBINGUMO SĄLYGĄ
}

\author{
Christoforos Ioannidis \\ Londono Karaliaus koledžas, Didžioji Britanija
}

\begin{abstract}
Anotacija. Straipsnio tikslas - pasiūlyti valstybès suvereniteta laikyti ketvirtaja valstybingumo salyga. Autorius ịvertina dvi pagrindines, tarptautinèje teiseje taikomas valstybingumo teorijas ir paaiškina ketvirtosios salygos problema. Straipsnyje autorius suvereniteto kaip ketvirtosios valstybingumo sąlygos samprata grindžia Buchanano deontologiniu argumentu, susijusiu su tarptautines teisès tikslu: užtikrinti teisinguma bei realizuoti pagrindines žmogaus teises.
\end{abstract}

Reikšminiai žodžiai: Tautos suverenitetas, valstybingumas, valstybingumo teorijos, Montevideo konvencija, tarptautine teisé.

\section{ARE THE CONDITIONS OF STATEHOOD SUFFICIENT? AN ARGUMENT IN FAVOR OF POPULAR SOVEREIGNTY AS AN ADDITIONAL CONDITION OF STATEHOOD}

\author{
Christoforos Ioannidis
}

King's College London, United Kingdom

Summary. In this article, the author proposes an idea of popular sovereignty as an additional condition for statehood. The author firstly evaluates the two main theories of statehood in international law, mainly the constitutive and declarative theory, and explains their deficiencies. Constitutive theory leads to the relativity of states. According to the declaratory theory, which was codified in the Montevideo Convention (1933) and is thus currently positive international law, the requirements for statehood are: a) a permanent population, b) a defined territory, c) a government and d) capacity to enter into relations with other states. The first three conditions are empirical and necessary and refer to the socio-political process of the creation of states. The fourth condition is problematic for two reasons. Firstly, it is logically circular, and secondly, it cannot be saved by reference to a main source of international law, namely state practice. Not only state practice cannot currently explain the fourth condition, but it is also logically impossible for it to do so because it falls in the trap of moving from conditions of statehood (recognition of a state), which are the conditions set by public international law for an entity to become a state, to conditions of recognition 
(recognition as a state), which are conditions based on which states decide whether to recognize other entities as states. If the fourth condition is abandoned, there seems to be a gap because the three remaining conditions are empirical, not legal. Thus, they explain the creation of an entity (non-legal term), not the creation of a state. They do not explain how that entity is elevated to a state, which is a full subject of international law. The author explains why there is a reason for a fourth legal condition to exist and suggests that the fourth condition ought to be popular sovereignty. Therefore, the author's argument is a deontological, not an ontological one, as it makes a suggestion regarding how international law ought to be, not about how international law actually is. The idea of popular sovereignty the author is suggesting is a very thin notion of popular sovereignty and is merely the historical fact that at some point in time, a permanent population living in an identifiable territory under a government voted for a constitution freely while the four standard requirements for freedom and individual autonomy were being satisfied. Further on, whether popular sovereignty is a necessary or sufficient condition for statehood is discussed. Then, the author tries to ground this suggestion of popular sovereignty on Buchanan's deontological argument regarding the goal of international law: the goal of international law ought to be justice, in the sense of realization of basic human rights. Finally, it is made clear that although in this theory a moral value, namely protection of basic human rights, becomes the primary goal of international law, this theory does not step into Natural Law.

Keywords: Popular sovereignty, statehood, theories of statehood, Montevideo Convention, international law.

Christoforos Ioannidis, tarptautinès teisès bakalauras, LLM, filosofijos magistras, Londono Karaliaus koledžo Diksono Puno teisès mokyklos doktorantas. Mokslinių tyrimų kryptys: tarptautinès teisès filosofija, jurisprudencija, tarptautinè viešoji teisè, žmogaus teisès.

Christoforos Ioannidis, LLB, LLM in International Law, MA in Philosophy, PhD Candidate at King's College London, The Dickson Poon School of Law. Research fields: philosophy of international law, jurisprudence, public international law, human rights law. 